\title{
Imperatives of Domestic Debt Payments And Economic Growth: the Nigerian Evidence
}

\author{
Ugwu Okereke J. (Ph.D) \\ Department Of Accountancy, Banking And Financeebonyi State University, Abakaliki
}

\begin{abstract}
The broad objective of this research work is to investigate the Effect of Domestic Debt Payments on Economic Growth in Nigeria (2000-2016). The quantitative design using ordinary least- square (OLS) method of multiple regression analysis was employed. However, secondary data for this study was obtained from CBN annual report, federal office of statistics and Debt Management Office. The finding indicates that domestic debt outstanding has significant relationship between Gross Domestic Product in Nigeria. Likewise, there is significant relationship between interest rate and debt servicing on Gross Domestic Product in Nigeria. The coefficient of determination indicates that about 85 percent of the debt variables (DDO, INT and IDS in Nigeria). This implies that a good portion of gross domestic product can be explained by changes in domestic debt variables. It is recommended that Government should maintain a bank deposit ratio below $40 \%$ and resort to increase use of tax revenue to finance its project. The regulatory authorities should provide enabling environment and policies for private sector investors with improved infrastructure
\end{abstract}

Keywords: Domestic debt, economic Growth, Nigeria, debt outstanding

\section{Introduction}

In less development conuntries government use public debt as an imperative tool to finance its expenditure. Economic growth can be increased by effective and proficient utilization of resources to achieve macro economic goals. However, if the public debt is not properly managed, it would restrict economic growth and become the highest curse for the economic such as inflation, fraud etc (Ramzan, Zahir and Taria, 2012).

Internal debt can be defined as an amount of money owned by the government to institutions, government agencies and other bodies resident in Nigeria (Ajayi, 2010). When government borrows, the debt is a public debt. public debts either internal or external are debts incured by the government through borrowing.

Debt is classified into two i.e. reproductive debt and dead weight debt. when a loan is obtained to enable the state or nation to purchase some sorts of assets the debt is said to be reproductive e.g. money borrowed for acquiring factories electricity refineries etc. however, debt undertaken to finance wars and expenses on current expenditures are dead weight debt.

Developing country like Nigeria is characterized by inadequate internal capital formation arising from the vicious circle low productive, low income and low savings. Nigeria is the world's sixth largest oil exporter but also one of the poorest. Nigeria domestic debt has been rising by escalating fiscal policy. Domestic debt has taken stage for conversing realistic pricing of petroleum products in Nigeria as the domesic debt profile has been rising astronomically and if not controlled could create some unfavourable consequences as crowding out private sector investment, poor GDP growth etc Okonjo Iweala (2011). On the other hand government has to continue to finance projects to grow the economy and viable option of doing so is by issuing debt intruments for example the 2012 national budget presented to national assembly contains a deficit of 1.1 trillion which has to be financed majorly through domestic debt. As at september, 2011 Nigeria domestic debt stood at $\$ 5.3$ billion dollar, and equivalent of $\$ 34.4$ billion dollar while debt was $\$ 5.6$ billion dollar bring the national debt to a total of $\$ 40$ billion dollar which amounted to 19.6 percent of GDP (Nwankwo, 2011), showing that the debt ratio is still below the international unacceptable standard of $40 \%$ of GDP. However, beyond consideration of maximum acceptable debt GDP ration of 0.40 a more critical consideration for economic growth in the country's absorptive capacity which might be quite below a given threshold. Asogwu (2010) Domestic debts are debts instrument issued by federal government and dominated in local currency, state and local government also issue debt instrument, but the debt instrument currently issued most consists of Nigeria treasury bills federal government development stocks and treasury bond. Out of these treasury bill and development stocks are marketable and negotiable while treasury bonds; way and means advances are not marketable but hold soley by the Central Bank of Nigeria (Adafu, and Abula, 2010).

The central bank of Nigeria (CBN) as banker and financial adviser to the federal government is charged with the responsibility for managing the domestic public debt. Alison (2003) reveals three principle reasons often advanced for government domestic debt. The first is for budget deficit financing, second is for implementing monitory policy and the third is to develop instruments so as to deepen the financial market. 
In Nigeria, several factors have been to explain the changing domestic debt profile and repayment between 1960 till date. Domestic debt payment as a percentage of GDP increased from 13\% in $1980-1989$ to $29.7 \%$ in 1990 - 1994 periods and 2000 - 2010 it's about 45\% (Asogwa, 2010).

This increase was a result of fiscal policy expansion embanked upon during the oil boom ear of the 1970's as the oil boom declined in 1980's priorities of government expenditure did not change (Jakob 2005).

Subsequently, the fiscal operations of the federal government resulted in large deficits from the average of $0.8 \%$ of GDP in the $1978-1989$ period, the deficit increase persistently averaging 5.15 in $1980-1989$ and $10 \%$ in $2000-2010$ (Adafu and Abula 2010).

An issue confronting the financial and corporate governance was as a result of fraud and financial recession. This arose major problem that has hindered the attainment of microeconomic stability and sustainable growth. The excessive reliance by federal government on borrowing from the banking sector particularly the CBN, to finance its large and unsustainable fiscial deficits, such borrowing from CBN amounts to the injection of high powered money into the system, which has affected the price and exchange rate stability. Similarly, this crippled the private sector from the credit market, therefore, retardating investment and output growth. Also the deficits budgeting thousands, is not the critical issue of concern, rather it is the size, sources of financing and quality of expenditure. The borrowed money must be prudently utility in the execution of productive projects in order to enhance the capacity for repayment of both the principal and interest element as they fall due.

A debt problem would naturally result when the resources that should have been employed for the execution of the productive projects are employed in the financing of debt. Large debts service payments imposed a number of constrains on a country's growth prospects it drains limited resources and curtails financial resources for domestic development needs large debt saving obligation and debt burden can depress investment and growth. It is therefore on this back drop that this study sterm study the implication of internal debt payment on economic growth of Nigeria.

The main objective of this study is to exmaine the impact of internal debt payment on Nigeria economic growth. The specific objectives include; to ascertain the impact of domectic debt outstanding on gross domestic products (GDP); to investigate the level of significant activities of interest rate on economic growth of Nigeria and to ascertain the extent to which internal debt service has contributed to the growth of GDP

The study focused on the implications of internal debt payment on economic growth in Nigeria. The research work relied mostly on the time series data for the year 2005 to 2016, when Nigeria was faced with economic recession as a result of poor utilization of internal debt and mismanagement of the entire economy.

\section{Literature}

Literature is scanty on the relationship between domestic debt payment and economic growth which most researchers are forecasting on external debt. Barro (1978) investigates the effect of domestic payment on economic growth using the unanticipated components of domestic debt or the debt stock and growth.He concludes that unanticipated components of domestic debt affect growth.

Kormendi (1983) he uses a cross sectional studies of 34 countries. The sample extends widely from the highly develop countries (the USA, U.K, Japan, Australia) to the underdeveloped countries (Sri Lanka). He concludes that debt and growth are not related. However, many of these critics viewed that their aggregation of such diverse group may not yield meaningful results.

Adofu and Abula (2010) investigated the relationship between domestic debts and economic growth in Nigeria for the period of 1986 to 2005. Outcome of their study revealed that domestic debt has affected the growth of the economy negatively. In the light of this finding, the study recommends that government's domestic borrowing should be discouraged and that an increment in her revenue base via tax reforms needs be encouraged.

Onyeiwu (2012) examined the relationship between domestic debt and economic growth in Nigeria. Result of this study found that domestic debt holding of government is far above a healthy threshold of 35 percent of bank deposit. This portends a crowding out effect on private investments. The study affirmed that the level of debt has negative effect on economic growth in Nigeria. The study recommended that government should maintain a debt - bank deposit ratio below 35 percent, increase its usage of tax revenue to finance developmental projects and to divest itself of all projects the private sector can handle while providing enabling environment for private sector investors and most importantly improved infrastructural facilities.

Aminu, Umaru and Musa (2013), asserted that domestic debts if properly managed can lead to high growth level. A major policy implication of this result is that concerted effort be made by policy markets to manage debt effectively by channelling them to productive activities (real sectors), so as to increase the level of output in Nigeria. Another policy implication of the study is what most developing countries contract debt for selfish reasons rather than for the promotion of economic growth investment through the capital formation and other social overhead capital. The paper rely more on domestic debt in stimulating growth rather than external debt. 
Gong and Zou (2002) suggested that volubility in government spending can positively or negatively associated; affect economic growth depending on the inter-temporal elasticity in consumption.

Cohen (2000) in his effort in examining the relationship between growth and debt of Latin America and African countries concluded the exchange rate mismanagement and over - valued exchange rates hurt protected economies, in particular were the economies are open.

Oxfam debt relief process opined that "the debt of poor countries effect their national development in many ways, with both economic and social consequences which our further compound by general poor economic performance. Even with concessional flow of finance and as described above, current debt relief mechanism, the debt service payments of a country remain un-sustained high links between impact in investment found due to the debt overhang and crowding out" effects. There is reduced access to financial market, and the instability created by a large stock of debt.

Borensztein (1990), was of the opinion that debt overhang had an adverse effect on private investment. The effect was strongest when private debt rather than total debt was used as a measure of debt overhang. Iyoha (1996) was of the opinion that heavily debt burden acts to reduce investment through both debt overhang and the crowding out effect.

Anyanwu (1986), opined that a whole scale of while elephant development projects in the country is the root cause of our debt problem. He says instead of emphasis being placed on small scale rural development projects so as to reverse the disbordered trend of urbanization and lessen the opportunity for corruption. Nigeria government started embarking on many illusory of which many are not productive.

Fajana (1993) sees nothing wrong with government borrowing, but the debt crises arises as a result of mismanagement of such funds. In fact he believes that borrowing is desirable and unavoidable because government borrowing is first order condition for bridging the domestic gap, the second order is that such fund should be invested on viable projects which rate of return is higher than interest rate on the loan. He summoned this by saying that for debt to serve as engine of growth, it has to be well managed and the resources it makes available needs to be efficiently and prudently utilized.

Ogwuma (1995) says that debt arise from loan and credit procured by the government from financial institutions or the rest of the world intended to bridge the savings investment gap. According to him when such resources are productively deployed they do not constitute a problem or a drain on the future resources. In order to ensure sustainability of debt serving, borrowing countries need to adopt efficient debt management strategies. He obersved that problem usually arise when more and more resources are deployed to serve the loan.

According to Ayadi (2008), Ayadi, Toluwase and Chatterjee (2003), debt burden had dramatically limited some countries participation in the world economic and the attendant debt servicing obligation countries to manifest as an impediment to economic growth and development means that a large debt stock discourages investments because potentials investors assume that there would be taxes on future income in order to make debt payments.

The macroeconomic instability relates increase in fiscal deficit, uncertainly due to execeptional financial possible monetary expansion and anticipated Qclaessen, Detragiache, Kanbru and Wickham (1996). The relevance of debt overhang hypothesis was stressed Audu (2004).

According to Audu the debt services burden militated Nigeria's rapid economic development and worsen the social problems. Edo (2002) was of the opinion that debt affected investment severely. He also opined that fiscal expenditure, balance of payment and global interest rates are major factors explaining debt accumulaion. The implication of huge debt is recognized Mutasa (2011). According to Mutala the heavy debt burden has been a major impediment to accelerated integration. Ajayi and Khan (2002) opined that indebtedness of African countries is becoming more acute for a number of reasons.

First, debt is enormous relative to the size of the economy and this had led to discouragement of investment. Secondly, debt servicing payments absorb a major proportion of funds and eat significantly into the funds that could be used to provide essentisl facilities to improve the welfare of a countries citizen.Third, debt burden threaten is not only the execution but also the prospects of success of adjustment programs. Forth, given the time spent on debt negotiation and its management, debt has nagative implication on an economy's overall growth and growth prospects.

Most of the studies reviewed above studies relationship between debt and economic growth, it is very clear from the reviewed literature that huge debt negatively impacts on economic growth but the direction of relationship is yet to explored debt burden has led to a limited accumulation of capital and medium-sized firms. This directly affects employment, literacy and poverty. Increase in savings and investment lead to economic growth Hunt (2007).

Sacha (2002) argues that growth will not increase until capital stock has risen to a given threshold. As capital stock rise, investment and output rises, the savings level will also continue to rise. After a given level, the rise in both capital and savings will be sufficient to engender self - sustaining growth. The reason for opting for debt, as a means of ensuring sustained growth rather than utilizing only domestic resources is provided by the 
"deal gap" theory. The theory postulate that investment is a function of saving, and that in development countries, the level of domestic saving is not sufficient to fund the needed investment to ensure economic growth and development. The acquisition of funds, however, depends on the relationship between domestic savings investment and economic growth.

Colaco (1983) explains the debt servic vulnerability in developing countries using three contexts. First, the size of the loan has reached a level that is much large than equity finance, resulting in an imbalance between debt and equity. Secondly, proportion of debt at floating interest rates has risen dramatically, so borrower are high directly when interest rate rises. Thirdly, maturities have shortened considerable. All the above factors are relevant in Nigeria.

Cohen (1993) and clement, Bhatharcharya, and Nguyen (2003) corroborate impact of debt, and they said that debet has a negative effect on growth and that negative effect works not only through its impact on the stock of debt, but also through the folow of service payments on debt, which are likely to 'crowd out' public investment and depress growth. The damaging implifcating of debt servicing on growth is attributable to the reduction of government expenditure resulting from debt-induced liqwuidity constraints (Taylor, 1993).

\subsection{Research Design}

\section{Methodology}

This study adopts ex-post facto research design. This was to enable the researcher determine the effect of internal debt payments on the economic growth in Nigeria. Moreso, due to the quantitative nature of the study, the study used annual data because quarterly data may not be assessable for some of the variables.

The data used for the study was secondary in nature. Those data were obtained from the publications of central bank of Nigeria statistical bulletin and debt manangement office (DMO).

The research variables of work are time services in nature and that are grouped into dependent and independent variables. Gross domestic product (GDP) employed as a dependent variable to measure internal debt payment on economic growth while domestic debt outstanding (DDO) interest rate (INT) and internal debt servicing (IDS) where employed as the independent variable as indicated.

It is argued that growth in investment facilitates economic growth the acceleration principle. Fosu (1996) argues that debt can additionally influenced economic growth. The model adopted is based on Adofu and Abula (2010) the Adofu and Abula (2010) model is specified thus. The stochastic model is: $G D P=B_{0}+B_{1}$ $D D O+B_{2} I N T+B_{3} I D S+U t \ldots(1)$

The Argumented dickey fuller (ADF) test was used to test for stationarity of the series. The above regression models constituted the basis for analysis in this work; statistical descriptive test was used to identify the characteristics of the research data to be generated. Presuming test for some of the basic assumption for multiple regression models was carried out the F-test statistic was used to test for linearity assumption. The null hypothesis for non-linearity was to be disagreed if the probability value of F- statistical is equal or less than $5 \%$.

This problem of multi collenearity arises when an approximated near relationship among explanatory variable lead to unrealizable regression estimate (doughty 1992). Here T- teswt can be used to assess whether the explanations provide by the equation as a whole is significant or not.

For the result of a multiple ordinary least square (OLS) regression to be adjusted efficient, certain basic assumptions are expected to be met. The T-test is used to determine the validity of the result.

\section{Results}

Descriptively, implication of internal debt payments on the eocnomic growth of Nigeria is a discretional instrumental analysis comprises of short-term, modern term and long-term debts, through which monetarily used to facilitate the control on demand and supply of money within the sectional eocnomy through fiscal policy as implementation tools is to be guided in addressing the policy. This chapter briefly analyzed the recorded research information into meaningful use. Iyilgwu (2002) stated that data do not become meaningful or useful until they have been analyzed. It was not possible or meaningful to resolve the hypothesis of the study until they collected data were used and scrutinize, using systematic analysis and verifiable techniques.

Table 1: Descriptive result in uunit root test (variable in level)

\begin{tabular}{|l|l|l|l|l|}
\hline Variables & ADF Test & $\mathbf{1 \%}$ Critical value & $\mathbf{5 \%}$ Critical value & Order \\
\hline GDP & 2.56 & -279.29 & -10735.12 & $1(0)$ Stationary \\
\hline DDO & -0.16 & -7.72 & -7.56 & $1(1)$ Stationary \\
\hline DS & 7.6 & -292.18 & 1284.57 & $1(0)$ Stationary \\
\hline INT & -10 & -7.72 & -2.28 & $1(1)$ Stationary \\
\hline
\end{tabular}

Source: Researcher's calculation using E-view 7.0 
The test shows that the variable RGDP and domestic debt outstanding (DDO) are stationary (integrated or order zero) at $5 \%$ level of significance. The rest of the variable are found to be stationery after differencing them once. The variable are therefore integrated of order one(1).

Table 2: Regregression result for the growth equation

\begin{tabular}{|l|l|l|l|l|l|}
\hline Variable & Coeff & STD.T & -Value & T-prob. & $\mathbf{R}^{\mathbf{2}}$ \\
\hline Constant & 2.56 & 0.4045 & 2.156 & 1.078 & 4.5796 \\
\hline GDP & 1.678 & 0.1705 & 0.9076 & 0.454 & 13.119 \\
\hline DDO & 0.454 & 0.072 & 0.382 & 1.191 & 18.029 \\
\hline IDS & 1.191 & 0.1882 & 1.003 & 0.502 & 12.313 \\
\hline INT & 0.502 & 0.079 & 0.423 & 0.212 & 17.623 \\
\hline DS & 0.212 & 0.0335 & 0.1785 & 0.0893 & 20.142 \\
\hline & 5.997 & 0.948 & 5.050 & 3.5263 & 85.802 \\
\hline
\end{tabular}

Sources: Researcher's calculatin using E-view 7.0

The regression coefficient of domestic debt outstanding in the estimate regression line presented above is 0.454 which shows that domestic debt outstanding has led to 45.4 increase in GDP within the period under study. The calculated t-statistics for the parameter or variable estimated of domestic debt outstanding is 0.382 . The tabulated on GDP of regressional analysis significance is 0.171 . In the regresswion we found out that, the value of the calculated T-statistics for domestic debt outstanding is greater than the value of the tabulated Tstatistics of GDP. This indicates that, the relationship between Gross domestic proudct (GDP) and domestic debt understanding is statistically significant.

The regression coefficient of interest rate in the estimated regressionline is 0.502 which implies that is 50 percent point increase in the interest rate during the peirod. The calculated T-statistics for the parameter estimated of interest rate is 0.423 and T- value of the T-tabulated. This implied that from the regressional analysis indicate the degreee of relationship between gross domestic produt (GDP) and interest rate is statistically significant at $5 \%$ level of coefficient.

The regression coefficient of internal debt servicing on regressional analysis in the estimated regression line is 1.191 which indicate increase in debt servicing led to 0.060 percentage increase in GDP. The calculated T-Statistics for the parameter estimated of internal debt servicing is 1.003 and the T-tabulated for GDP is 0.171 . The value of the calculated is more than the value of the T- tabulated. It therefore swhows that the relationship between GDP and internal debt servicing is statistically significant at 5\% level of significance text.

The coefficient of determination is of is $\left(\mathrm{R}^{2}=85.502\right)$ indicates about $85 \%$ of variation in gross dometic product (GDP) in Nigeria can be explained by changes in the domestic debt variable (DDO, INT and IDS). This implies that a good portion of gross domestic product trends in the economy is explained by the domestic debt variables. There is a positive significant relationship with gross domestic product in Nigeria. This is also strong because the coefficient of the edxplanatory variable is statistically above $5 \%$ significant level.

With reference to the above table, the coefficfient value and standard error respectively are 0.454 and 0.072 . The T-statistics is 0.382 and the probability of the t-test statistics at $5 \%$ level of significant. It is significantly positive as against the null hypothesis. Based on these factors we reject the Ho hypothesis and therefore concludes that the domestic debt outstanding has significant impact on growth of GDP.

To what extent has interest rate not impacted on economic development of Nigeria? The test result as contianed in table 4 indicates that the coefficient is 0.502 and the standard error is 0.079 . The statistics 0.423 with t-probability 0.212 this shows that lack of support for the null hypothesis and acceptance of the alternative that interest rate has impacted significiantly on the economic develoment of Nigeria.

To determine the extent in which internal dept servicing has not contributed to the growth of GDP. The test result as contained in table 4 indicates that coefficient is 1.191 and the standard error is 0.188 of t-test statistics is 1.003 with probability of T-test statistics of 5\% level of significance. It is significant and negative and agrees with alternative hypothesis. Based on these factors, we reject the Ho hypothesis and accept $\mathrm{H}^{1}$ and therefore include that internal debt servicing has significant impact on growth of GDP.

\section{Conclusion}

The study shows a significant relationship of domestic debt payment on economic growth of Nigeria, as against the null hypothesis. Therefore, the study is of the opinion that government, policy maker and productive sector should work together to ensure stable economy. This will be enhance through the provision of macro-economic environment and appropriate investment incentives. The inbvestors are expected to reciprocate the gesture through commitment to the funds and promptly honoring loan obligations. Government through its relevant authorities should design favourable monetary policy that would enable domestic debt to made available for private sector at affordable rate (this is because low credit or high ledning rate will amount to low lebvel of investment which transmit to low out put) for massive development of the sector. 
Government should maintain a bank deposit ratio below 35\% and resort increase use of tax revenue to finance its project-government should divest all projects which the private sector can handle compatibility in budget implementation, estimation rolling plan, refining crude oil (petroleum product) and transportation.

The regulatory authorities should provide enabling environment for private sector invewtors such as tax holding, subsides, guarantees and most importantly improved infrastructure.

\section{References}

[1]. Adofu, J. \& Abula .M. (2010). Domestic debt and the Nigerian economy.Current Research Journal of Economic Theory 2(1): 2226.

[2]. Alison J. (2003). Key issues for analyzing domestic debt sustainability. Debt Relief International Publication ISBN 1-90 3971-07-1.

[3]. Amino H. \& Musa S. (2013). External debt empirical and domestic debt impact on the growth of the Nigeria economy, Eyesy Publishers PP 309-312.

[4]. Ajayi E.A. (2010). Nigerian Debtt Management Experience Journalist-Central Bank of Nigeria 13(2)406-432.

[5]. Ajayi E. A and Khan B. (2002). The Feasibility of democracy in Africa Dakar CODESRIA books.273-275.

[6]. Anyanwu J.C (1986). Suggeswted Solutions to Nigeria’s Public Debt Problems. Business Jones July 4.

[7]. Asogwa R.C. (2010). Domestic Government Debt Structure. Risk Characteristic and Non Monetary policy Conduct evidence from Nigeria access http:www.info.org/external/np/res/Sr,omstd/2007/macro/pdf.

[8]. Audu I. (2004). The Impact of External Debt Economic Growth and public investment: the case of Nigeria. African institute for economic development and planning (IDEP) Dakar Senegal http:/www.unidep.org.

[9]. Ayadi, F.S \& Ayadi F.O (2008). The Impact of External Debt on Economy Growth. A Comparative of Nigeria and South Africa; Journal of Sustainable Development in Africa 10(3) pp.33.

[10]. Barro, R. (1978). Public Debt and Taxes. In Boskin .M. (ed). The federal tax reform: Myths and realities institutes for contemporary studies, San-Fransisco.

[11]. Borenaztein E. (1990). Debt overhand, credit rationing and investment. Journal of development economic. T 32.pp 315-335.

[12]. CBN (2005). Statisitical Bulletin, central Bank of Nigeria December Vol 16 access Htt;p://www.centralbank.org/out/publication/reports/rd/2007/stabull2015-pdf.

[13]. Cohen D. (1993). Low Investment and Large LCD debt in the 1980's, The American Economic Review. 18(3). 54-60

[14]. Clements. B., Bhatharcharya, R. \& Nguyen T.Q. (2003). External Debt, Public Investment and Growth in low income countires. IMF Working paper N0. 03/249

[15]. DMO, Nigeria's debt and Nigeria economy retrieved from http//www.dmo.gov.ng/pub.phd $12^{\text {th }}$ august 2016.

[16]. Edo, Samson E.(2002). The external debt problem in Africa: a comparative study of Nigeria and Morocco's. African Development Review. 2 pp 221-236.

[17]. Fajana, F. O (1993). Nigeria Debt Crisis, United National Economic Commission for African Socio-economic research and planning division, Addis Ababa, Ethiopia, 5(2):54-57.

[18]. Gong L. \& Zou H. (2002). Effect of growth and volubility in public expenditure on economic growth: Theory and Evidence. Pecking University Press. Pp 376-381.

[19]. Hunt S.D (2007). Econinc growth should be policy focus on investment on dynamic competitions. European busniess review 19(4) 279-291.

[20]. Jakob C (2005). Domestic debt market in Sub-Sahara African-special data section staff pap-52 (3): 518-538.

[21]. Kormendi, Roger, C. (1983). Government debt, government spending and private sector behaviour American economic review. 73(5). Pages $994-1010$ December.

[22]. Mutasa, C. (2003). Regional integration and debt in African: A comparative report of African's Regional Grouping AFRODAD Research series.

[23]. Ogwuma P.A. (1995). Revitalizing the manufacturing sector in Nigeria. Central bank of Nigeria. A Selection of Essays/speeches by the governors.

[24]. Onyeiwu C. (2012), domestic debt and the growth fo Nigeria economy: Research Journal of Finance and Accounting Jewzey Publisher 3(5) pg 102-105.

[25]. Ramzan M.S., Zahir F.M. \& Taria, K. (2012). Domestic debt and economic growth in Pakistan an empirical analysis. Pakistan Journal of Social Sciences (PJ55) 30, (2) 373-387.

[26]. Sachs J.O. (2002). Resolving the debt crisis of low income countries. Brooking papers on Economics Activity 1-28.

[27]. Taylor J.B (1993). Microeconomic policy in a world economy: from economic design to practical operation, New York: W.E. Norton. Edith hallmark publisher pg 401-402. 